\title{
Cronies, Rents, and Import Licenses: Non-tariff Trade Controls throughout Import Substitution Industrialization (ISI) in Mexico*
} Socios, alquileres y licencias de importación: controles comerciales no arancelarios durante la industrialización por sustitución de importaciones en México

\author{
Alejandro Castañeda \\ Master of Philosophy (MPhil) \\ London School of Economics and Political Science, United Kingdom \\ alexcastaneda82@gmail.com
}

\begin{abstract}
This paper fills a gap in the literature about import-substituting industrialization (ISI) by analyzing non-tariff trade controls, mainly import licenses, with a focus on Mexico, a case that has not been studied in detail. The core questions addressed include: Which specific pattern licensing were followed? What was the economic rationale behind such pattern?, and is there evidence that non-tariff controls were 'captured' that is, facilitating rent-seeking? In order to answer these questions, the project takes a qualitative and quantitative approach, using primary evidence gathered in archives as well as statistics from secondary sources, which are combined in
\end{abstract}

This paper summarizes chapter 3, of an M. Phil. thesis submitted to the Department of Economic History of the London School of Economics for the degree of Master of Philosophy, London, January 2012. 
novel ways. Specifically, here we provide descriptive statistics of the licensing system, and demonstrate that the policy lacked internal consistency, an overwhelming majority of products were protected for far longer than officially specified, and that illegal source of rents from trade — smuggling and "free perimeters" - were significant. The main findings, which shed light on larger debates about ISI are that excessive protectionism was neither effective nor sustainable and that cronyism characterized the post-Second World War process of industrialization in Mexico.

Keywords: Rent-seeking, import-licensing in Mexico, protectionism, economic history.

JEL Codes: D72, F13, N76, O14.

\section{RESUMEN}

Este artículo pretende llenar un vacío en la literatura sobre la industrialización sustitutiva de importaciones (ISI) mediante el análisis de controles comerciales no arancelarios (principalmente licencias de importación) en México, un país en el que este asunto no ha sido estudiado en detalle. Las preguntas centrales abordadas son: ¿qué patrón de licenciamiento específico siguió este país; ¿cuál fue la razón económica detrás de dicho patrón?; ¿existe evidencia de que los controles no arancelarios fueron "capturados" para facilitar la búsqueda de rentas? Para responder estas preguntas, el proyecto adopta un enfoque cualitativo y cuantitativo, utilizando evidencia primaria obtenida de archivos y estadísticas de fuentes secundarias, las cuales se combinan de formas novedosas. Específicamente, este trabajo proporciona estadísticas descriptivas del sistema de licencias para demostrar que la política carecía de consistencia interna, la protección otorgada a la abrumadora mayoría de los productos durante mucho más tiempo de lo que se especificó oficialmente y que la fuente ilegal de rentas del comercio, es decir, el contrabando y los "perímetros libres", tuvo un valor significativo. Los principales hallazgos, que arrojan luz sobre debates más amplios sobre la ISI, señalan que el proteccionismo excesivo no fue efectivo ni sostenible y que el clientelismo caracterizó el proceso de industrialización posterior a la Segunda Guerra Mundial en México.

Palabras clave: búsqueda de rentas, licencias de importación en México, proteccionismo, historia económica.

Códigos JEL: D72, F13, N76, O14. 


\section{INTRODUCTION}

The aim of this paper is to present selected qualitative evidence for protectionist rents accrued through the import-licensing and for the efforts to secure them. A selection of quantitative evidence gathered from primary sources is also presented in order to reach a wider picture of rent-seeking facilitated by non-tariff trade controls throughout ISI in Mexico.

As often in economic history, the evidence is patchy, incomplete and of heterogeneous quality; it does not cover whole economic sectors nor long periods of time due to inherent limitations in the materials available in the National Archives (AGN). Yet, it is a valuable set of primary evidence that had never been analyzed. As such, the materials provide a window into rent-seeking activities during the 1950s, which is a period of "transition" for ISI in Mexico; that is, when serious efforts were directed towards the substitution of intermediate and final goods. It is the "deepening" or "vertical" substitution period that coincides with unprecedented growth of both the economy and the state. Roughly, the evidence covers two administrations or "sexenios", that of Adolfo Ruiz Cortines (ARC), from 1952 to 1958, and that of Adolfo López Mateos (ALM), from 1958 to 1964.

At any rate, by the late 50 s the substitution of simple, cheap consumer goods had been completed. By some econometric measures, 1958 represents a structural break in terms of the income-elasticity of demand for imports, since it was only after that year that such measure was lower than one. The establishment of new industrial projects meant less imports of finished goods, but more of intermediate and, especially, capital goods. In this context, trade policy became more relevant than ever: import licensing, albeit at first justified by deficit worries, became the preferred way of granting protection.

However, its repercussions became more difficult to handle, as granting protection to producers of inputs (not only to final products) often meant rising costs for all domestic producers. Thus, privileged access to government officials or the ability to influence, bribe or blackmail the government concerning import access/control could make a crucial difference.

The documents can be classified as follows: (i) letters submitted by private firms asking for tariff protection and/or qualitative controls; (ii) requests for import permits for inputs; (iii) internal documents from the Ministry of Trade and Industry (SIC) assessing specific cases and requests; and 
(iv) letters from officials who, for various reasons, wanted to disclose information about sensitive cases.

All documents were gathered in the AGN in Mexico City, mainly from two core sub-sets: Presidential archives and correspondence (which include ARC and Miguel Aleman Valdes, MAV) and SIC records contained in the "Fondo 217", which comprises all the materials available on trade policy. Unfortunately, the Sub-secretary of commerce (where import-licenses were actually produced) is missing from "Fondo 217 ", which means that documents available on trade policy are so because there was some sort of overlap with industrial policy.

\section{THEORETICAL FRAMEWORK}

The theoretical foundations of the rent-seeking framework are based primarily in the works of Tullock (1967), Buchanan et al., (1980), Stigler (1971), Krueger (1974, 1975), and McChesney (1997). Different streams in the neo-classical economic literature ${ }^{1}$ developed during the seventies and especially the eighties; broadly speaking, it is possible to identify at least four categories:

- Theoretical developments involving mathematical models, with a strong emphasis in game-theory approaches.

- Regulation and Protection stream (Stigler, 1971), also known as the Theory of Economic Regulation (TER).

- Economic development and growth stream (Krueger, 1974, 1975; Murphy et al., 1991), term coined by Krueger.

- "Political and legal institutions" stream - mostly, McChesney (1997) - and the Rent extraction and rent creation approach", as a refined and expanded TER framework.

Standard neo-classical definitions of rent and rent-seeking are as follows: "Rent is that part of the payment to an owner of resources over and above that which those resources could command an alternative use. Rent is receipt in excess of opportunity cost" (Buchanan et al., 1980, p. 3); rent-seeking: "The resource-wasting activities of individuals in seeking transfer of wealth through the aegis of the State" (p. 2).

By no means this is the only relevant literature on rent-seeking. The M. Phil. thesis discusses the seminal work by Khan and Jomo (2000) and others who provide evidence of the positive role that "learning rents" played in the development of East-Asia, whereby conditionality was successfully imposed in some countries. 
A crucial distinction vis-à-vis profit-seeking and rents accrued from technological innovation is the contrasting outcome for society at large: while technology creates value, rent-seeking merely diverts resources. The socially harmful consequences stem not only from sustained rents but mostly from potential entrants engaging in seeking such rents for themselves.

Another key insight from Buchanan et al. (1980) emphasizes the capacity of the state to create artificial scarcities (through policies that create [and limit] rights: licenses, quotas, permits, approvals, etc., along with regulation) which entail potential rents to be sought after by private actors and/or actively offered by State actors.

In his seminal paper, The theory of Economic Regulation, Stigler (1971) proposed what was then a novel approach to regulation: that of an exchange, by which there are benefits the state can provide to industries (as opposed to mere constraints, as it was thought) at some particular costs. In that sense, Stigler asks (i) who will receive benefits/burdens of regulation, (ii) what form regulation will take, and (iii) what the effects of regulation upon the allocation of resources will be (Stigler 1971, p. 3). To summarize, Stigler makes a case of regulation as being subject to supply and demand dynamics (as opposed to the "normative" approaches to regulation) whose outcome is rent creation.

However, the early TER approach was criticized on at least two fronts, resulting in a more refined theory and in significant advancements such as McChesney (1997). First, some authors, such as Richard Posner (1974) noted that numerous pieces of regulation did not benefit producers at the expense of consumers. Second, the politician appears as a mere "faceless broker" surrounded by private demands, rather than having his own initiative. In response to the first caveat, the "cost predation"/ "raising rivals' costs" model was proposed; the second gave rise to the "Rent extraction" approach advanced by McChesney (1997).

The "Rising rivals' costs" model - still one of rent creation - focuses on "infra-marginal" rents: those created not primarily at the expense of consumers but at the expense of other firms within the industry; that is, regulation that will increase costs for all firms, but proportionately more for marginal firms.

Conceptually, the implication for the analysis of import licenses is as follows: under a system of discretionally allocated quotas/quantitative controls, firms not getting the permits for imported inputs (the majority) will 
see their costs rise substantially, while those that did get the licenses will see them decrease in a context of high prices. That is to say, import licensing can be a highly effective "rising rivals' costs" device: protection raises the price of a previously imported input for all the industry, but those few, connected firms will have privileged access to cheaper imports.

Such framework also fits squarely with the seminal work by Krueger: "when quantitative restrictions are imposed upon and effectively constrain imports, an import license is a valuable commodity" (Krueger, 1974, p. 291); thus, it follows that resources will be devoted to competing for those licenses.

In addition, competition can also occur through allocating resources to influencing the probability, or expected size, of license allocations. Some means of influencing the expected allocation--trips to the capital city, locating the firm in the capital, and so on are straightforward. Others, including bribery, hiring relatives of officials or employing the officials themselves upon retirement, are less so. In the former case, competition occurs through choice of location, expenditure of resources upon travel, and so on. In the latter case, government officials themselves receive part of the rents (Krueger, 1974, p. 292).

Ultimately, Krueger's work stands out for the empirical insights that proved her approach to be true and significant; she estimated the value of import licenses in Turkey (for 1968) as three times that of total imports, while the overall cost of licenses as percentage of GNP reached a staggering $15 \%$ (7.5\% in India) (Krueger, 1974, p. 294). Such is the economic relevance of import-licenses. Furthermore, institutionalist approaches to Crony Capitalism in Latin America -notably, that of Haber (2002)- stress how temporary, non-tariff controls, conveniently used as patronage by the government, became subject of intense lobbying or even outright capture.

\section{METHODOLOGY}

\section{Qualitative Evidence}

Translated into a particular methodological framework to deal with both the licenses and trade restrictions (i.e. the rents accruing from them), the following categories are used:

- Monopoly rents: that is, import-licensing (along with tariffs) used as a device to create artificial scarcities by getting rid of foreign competition; a captive market for one or few firms. Conceptually, what 
matters here is that rents are accrued at the expense of consumers and that they are the indirect outcome of licensing, as opposed to those who actually exercise the right to import banned items (legal "rent-creation" sought primarily by firms).

- Rising-Rivals'-Costs rents: in this case, import-licensing is used to get an artificial advantage vis-a-vis other firms within the same industry: prices need not to be raised, as the firm's costs will be kept lower than those of its competitors. That is, rents at the expense of other firms (legal "rent-creation" offered/threatened by active politicians or bureaucrats).

- "Money-for-nothing" rents: these are payments often exacted as plain extortion or blackmail: can take the sophisticate forms of threats to reverse particular policies or measures or the straightforward form of asking money not to retain goods at the customs, even though all the legal requirements have been met: it is literally money for not doing anything (a continuum from legal to illegal "rent-extorsion").

This categorization, in turn, was used as analytical framework for all cases that were found in the National Archives (AGN) of individual firms and industries seeking protection (from 1940 to 1980), through:

- Letters submitted by private firms asking for tariff protection and/ or qualitative controls.

- Requests for import permits for key inputs.

- Internal documents and memorandums from the Ministry (SIC) assessing specific cases and requests.

- Letters from officials who, for various reasons, wanted to disclose information about sensitive cases.

All documents (unpublished materials) were gathered at the AGN, from two core sub-sets: the Presidential archives and correspondence, and $\mathrm{SIC}$ records contained in the set known as "Fondo 217," which comprises all the materials available on trade policy. The quotes pertaining to National Archives (AGN) materials are the numerical references under which the materials were found and are organized. 


\section{Quantitative evidence}

In order to get central-tendency measurements of non-tariff trade controls (i.e., import-licenses) from 1947 to 1980, a data-set was developed from around 3,800 individual official decrees (known as "DOF", the official gazette) pertaining to the inclusion of both specific items and (or) general product categories into the list of "banned" imports (i.e., licensed).

Specifically, the data-base sorted all decrees by "type" attached to it, either:

- Inclusions: items henceforth banned from importation.

- Corrections: in Spanish, fe de erratas, that means, most of the times, misspellings or in some cases wrong items.

- Deferrals: meaning that the exclusion has been deferred; that is, a de facto extension of protection for the particular item).

- Reversals: those items whose importation would no longer require a permit.

The aim is to carry an analysis of the both the nature and timing of decrees declaring specific items as banned, to answer whether there the licensing system was internally consistent and whether redundant protection was being granted.

\section{MONOPOLY RENTS}

\section{Tin Industry}

The relevance of this case stems from the fact that it was not only a heavy industry but also because demand for tin soared as import substitution went further. This is especially true considering that by the late 50 s the state-owned steel and metal company "Altos Hornos" was fully operational, accounting for a significant proportion of demand: 30\% in 1958, according to the Ministry's own reports (see below). In addition, plants manufacturing electric devices were also establishing by the time, with General Electric and Westinghouse as the main producers.

The account of this case is provided by a set of six documents; two are internal papers providing data and information about the industry, whereas the other four are letters sent by and to the three incumbent firms and the SIC. The case is somewhat complex, but the letters show how in a context of rapid demand growth, the tin oligopoly tried to maintain the 
domestic market closed to imports, and thus take advantage of the worsening scarcity of tin.

On the other hand, it also shows a relatively common practice in the metal and mineral industries, namely, saving on the processing by "temporarily" exporting the minerals and then re-importing the metal plates. In this context, the potential sources of rents are numerous: (i) first and foremost, by banning all tin imports while demand for it increases, effectively charging monopoly prices; (ii) by blocking all attempts to temporarily export the minerals, thus charging higher price for the processing; (iii) by getting a sole permit to export and/or import, which would mean that even selling at the same price profits would be higher as costs were substantially lower (in this particular case it's about the RRC model).

From the Ministry's report it is possible to establish some facts about the tin industry. First, domestic supply was not growing fast enough, therefore imports had to compensate for it; tellingly, exports had completely halted by 1958 as a result of the soaring internal demand. As the letters show (see below), this context made the licensing of tin imports even more relevant, since blocking them would secure monopoly rents to producers.

The market was per se oligopolistic, since there were only three firms producing tin plates: Minero-Metalurgica de Estaño (MME), Estaño-Electra (EE) and Compañía Estañera Mexicana (CEM). Furthermore, only EE had the capacity to fully process the tin (that is, extraction, melting and casting). The other two were not able to cast tin plates and their production was carried with "antiquate means," according to the report. On the other side, demand came from 8 firms and five industries: Altos Hornos, La Consolidada, La Modelo, General Electric, Westinghouse, Mata y Gonzalez, German Sommer, Gustavo Sommer, Telmex. The relevant industries were newspapers, prints, Pharmaceutical labs, Tobacco firms, chocolate makers and car manufacturers. By 1959, tariffs were $\$ 0.15$ Mexican pesos per kilo and ad-valorem of $15 \%$ (official price was 30 pesos per kilo).

This first report notes the advantages exporting firms were given with export permits; this, made evident by the fact that all had opted to temporarily export the mineral rather than buying the services from local firms. In a first attempt to support domestic industry, the Ministry tried to force those firms to do business with their partners: 
Current Import controls allow for total domestic production of tin to be sold, as well as to allow consumers to import if they need more, depending on their needs. [thus] Tax exemption to exporters of tin minerals (than re-import the processed tin) should be changed as there is a plant capable of producing tin with a $99.9 \%$ grade. Refusals to temporarily export tin minerals are based on the fact that one firm - Estaño-Eléctrica, S.A. de C.V - is willing to lower its prices as long as the exporters commit themselves to supply at least five tons of minerals per month. The frequency with which requests for temporary exportation of tin are submitted tells us about the apparent ignorance about the existence of this firm. Once asked directly, would-be exporters claim that EE asks for prices all too high. Exporters' insistence suggests it might be the case that they would export low-grade minerals only to re-import (cheaper) tin, thus taking advantage of its scarcity in the country. Given these reasons, it is considered to be right to deny temporary export permits, on the one hand, and to plan a general meeting with both exporters and processers as to achieve an understanding between the two sides (AGN, Fondo 217: 554, Vol., 511.01/727, Exp., 7).

The second document available is a letter addressed to Departamento de Fomento, dated October 29th, 1959, and sent from Cia. Estañera Mexicana (CEM), which was the first one in the country. It does give an account of rents recently secured and the threat import licenses did pose to them.

It starts giving some context and observing that international prices had gone down in 1958 and had only recently recovered to its previous level of USD 1.03 dollars per pound. The domestic market had followed a similar upward pattern, although for different reasons: new production lines using up more tin plates and a shortage of the mineral. In turn, the scarcity commanding higher prices was attracting more investment and production, precisely what CEM was doing. Interestingly, they note that expanding production was only possible after having found "finally, capable functionaries whose vision, backing and help have been crucial; above all, the stabilization of the domestic price" (Ibid, emphasis added). In other words, they would not invest without knowing that profitability was going to be maintained.

Next, the document remarks the goals the firm will help to achieve: (i) development of a new source of wealth, not exposed to external fluctuations, (ii) saving foreign currency, thus helping to reduce the deficit in the 
current account, (iii) jobs in the primary sector and the industry, and (iv) the ability to produce what the country consumes. Having set the stage, CEM then raises the issue of recent importation of tin, and then goes on plain blackmailing, openly blaming the government policies for job layouts:

We will find ourselves - just as other firms in the industry - in the need of halting production and get import permits as well -which could not be denied-to meet demand from our clients. Thus, not only casting will be suppressed but jobs as well [...] miners will again abandon their work, to which they won't come back because of having been despised, so they will migrate or face an increased poverty. We, that have fought to give Mexico a new industry, will completely lose our morale and money invested. In sum, this newly born industry will die (AGN, Fondo 217).

The threat of job layouts would in fact become part of the discourse amongst businessmen. This has been pointed out in seminal works on Mexican industrialization (Rubio,1990, p. 249).

At any rate, it is clear that stakes were high for CEM. The firm was aware of the steady increase in domestic demand for tin, which couldn't possibly be met with local production; however, their profits were inversely proportional to the quantity imported.

Only two days later, another letter was sent to the SIC, this time from MME. Although not as big as CEM, it was nevertheless an important player in the industry. The letter itself has the same purpose; however, the tone is far less threatening. Mr. Heinze Sierra, the manager, points out the apparent contradiction in policy as the government banned temporary exportation of raw mineral but at the same time allowed tin imports. This was relevant as MME was setting up an electrolytic plan for refining tin and given that regulations forced them to buy local supplies, Mr. Heinze noted that with such cost structure they would never be able to compete against American tin. It followed that the new plant would be a big-time failure if the government kept the market open to imports.

We therefore kindly ask you to take our case into consideration, and if our petition seems as a justified one to you, to ban outright all import permits for tin. Refraining from doing so would mean that granting licenses to all firms would be a better option than producing it domestically (AGN, Fondo 217: Vol., 557., Exp., 14).

The appendix also argues that it has been customary for the government officials to "consult" with the firms in the industry every time there was 
an application for import licenses before reaching a decision. However, "in the aforementioned cases we've never been notified about the application for such permits" (AGN, Fondo 217: Vol., 557., Exp., 14).

The answer from the SIC was sent on November $11^{\text {th }}, 1959$, (SIC letter classified as 391-III-21076) but did not compromise the government's position. It limited itself to the acknowledgement of MME's position and request. As it will be shown, Mr. Heinze's irritation would only grow.

The third letter is dated April 27th, 1960, and was sent to the SIC by MME. Attached comes another letter, sent to the official in charge of the committee for iron and steel imports, also in charge of tin imports. In sum, the firm is accusing Mr. Roberto Hernández (head of committee) of lying; he had paid a visit to the plant in December 1959, by which he attested the existence of large stocks of unsold tin. The government official committed himself to ban henceforth all tin imports to get MME's stocks sold.

Even though in such occasion Mr. Hernández could see the unsold stocks and therefore made clear that import licenses for tin will be denied, those imports have continued to get into the country at the expense of our firm. We thus expect this department which is called "industrial protection" to effectively block such imports that, we repeat, are a real threat for the domestic tin industry (AGN, Fondo 217: Vol., 554, Exp., 7).

The letter addressed directly to engineer Hernández is less polite in its language and clearly reveals (again) the irritation of the firm owner, Carlos Heinze:

You did tell us (during the visit) that out of any doubt, permits for tin imports would be denied; however, most of those firms (that would be denied the permits) have shown us imports of tin they've recently made, a fact we find utterly surprising given that you by yourself could see the tin stocks we have [...] thus we kindly request accurate information about whether or not the government will keep granting such permits (AGN, Fondo 217: Vol., 554, Exp., 7).

The next letter, dated the 27th of May, shows also that the tin industry faced a far more complex situation than a mere clash between local production and the 116 competing imports. The clash was also about the export permits, as some firms, quoting lack of enough processing capacity, would send the mineral to the US and then re-import it as cast tin. It was a mere commercial operation that did not require any plant; thus, it was profitable enough. So, Mr. Heinze was reminding the SIC that his firm agreed to follow 
government's plans as to expand and improve casting capacity in order to achieve a $99.9 \%$ purity (in line with international standards), one of the reasons quoted by other firms not to buy local tin. Now then, MME wanted the government to ban such export permits as to force other firms to process the mineral in the country:

The improvement of the plant (electrolytic process) has had an extremely high cost relative to the scale of our plant; nevertheless we decided to go ahead in order to align ourselves with the government's goal of industrializing the country as far as possible... the firms doing such temporary exporting are not in fact part of the tin industry, they are only trading [...] therefore, the only thing they need is to have enough liquidity, and given that such operations are often backed by financial firms, the business can be carried out despite its profits margins being so low, given that they are spared of labor and machinery expenses [...] therefore, we kindly ask those export permits to be banned (Ibid).

Mr. Heinze's words were far from enough to convince the government. By August 10th, the SIC sent a document to customs officials authorizing "Metales Potosi" to temporarily export 200 tons of the mineral for refining in the US and re-importing them into the country. The document quotes the "Oficio 309-vi-2642" that had previously banned such movements and cancels the decision (despite Mr. Heinze's wishes). Moreover, the study made by the Unit of fiscal research argues precisely for supporting such practices. Amongst the reasons exposed, there was evidence that processing capacity was still not enough to meet demand of cast tin, as well as evidence of monopolistic pricing, since there were only two plants able of processing. Thus, the study argues that temporary export-import permits should be given until processing capacity matches demand, a goal achievable in a year and a half, and adds that firms involved have agreed on this -with the understanding that exports permits will last until capacity is readily available.

The document also proves that processing firms were accruing monopolistic rents typical from protectionism:

From the research done by the fiscal unit, it follows that processing firms currently in the market have been charging excessively high prices: they charge three times as high compared with US processing plants. The excess portion of the price is considered as unjustifiable since by no means it is related to a higher costs structure but rather it is a consequence of the monopoly in which they operate. [...] It is thus predicted that, if 
we allow such high price in processing affect the price of the tin plate, the domestic price structure would be affected as it an essential input on many consumer goods (AGN, Fondo 217: Vol., 554, Exp., 7).

The document also has a paragraph on conditionality: it emphasizes that export permits are tied up to expanding capacity. If they take more than the agreed time, the Treasury would impose an export tax, in fact eliminating the cost advantage of the scheme: "In case of not complying with such condition, the Ministry of the Treasury will impose the relevant taxes over the quantities of mineral that have been exported under the scheme."

Interestingly enough, only one firm was granted the permit - Metales Potosí de Pizzuto - which may or may not have been the result of policy; if all firms were given permits, they could simply keep a price-fixing scheme. However, not granting them all could mean an attempt to improve competition (since the firm not being granted would be forced to lower its price).

A letter next September by Estaños Mexicanos shows this: the firm is addressing the SIC to enquire about the delay of the permits: "by enquiring about it we do it only because we know that Metales Potosi was already granted a permit, even though they applied for it after we did. So, we expect to be granted the permits as soon as possible, just as we presume the reason it has not been done already is because of mere administrative backlog."

The missive was followed by another one from MME (Mr. Heinze's firm), which shows the increasing irritation of the owner. He denies not only having signed any agreement but even having been informed about the shift towards export-import permits. He complains of never being granted with such permits and tries to blackmail the government by referring to the "commitment" they had towards the firm: they would invest in a new processing plant and the government would ban all temporary export permits (that is, securing the monopoly rents).

The accusations are rather direct: "It is absurd that now exports are being authorized for being processed in the US (after imports had to be brought in to cope with a shortage) unless it meant to give an advantage to someone who is neither in the mining sector nor in the tin industry." The person he is referring to is Mrs. Socorro de Pizzuto, who indeed was granted with the export permit and is mentioned by her name in the document. It is then suspicious enough that two out of three firms did not get the export permits. 
However, it is also true that Mr. Heinze implicitly acknowledges that he would do same: "Our indignation comes chiefly from the fact that we ourselves have made countless attempts to get such export permits; however, such efforts have been for the most part unsuccessful."

The letter finishes reminding the SIC not only about the investments already done in the new plant but also the commitment towards the firm:

Given the aforementioned reasons, and given that the SIC encouraged us to build the new plant, we consider there is a commitment towards our firm, so the government should keep its word: export permits ought to be banned, since there is already local capacity to process the minerals (AGN, Fondo 217: Vol., 554, Exp., 7).

In sum, firms in the tin industry did invest to expand capacity, but once operating, were expecting the government to secure the entire market for themselves. This was initially the case, but, consequently, the price of tin reached USD 3.16 per pound (versus USD 1.03 if imported), a substantial rent accruing to three firms. Given that tin was a key industrial input, a higher cost would push the general price level up. But inflation was too high a political cost for the government (and President Ruíz Cortines is regarded as being legitimately concerned about it), so licensing in this case could have been used to limit rent-seeking. Other products with fewer repercussions, however, were less likely to get such attention from the government.

\section{“RISING-RIVALS' COSTS” (RRC) RENTS}

\section{The Soap Industry}

Interestingly, the case of soap, detergent and lard shows that not all producers could get competing imports banned completely and just by arguing that these damaged the "nation's interests" (as it was often the case). The industry's concerns were relatively familiar to public opinion as the chamber of oil producers displayed an aggressive media campaign. An open letter published in the Universal newspaper (the most important) the 10th of August 1950. In it, the chamber makes clear that imports of lard (as an input for soap) and synthetic cleaners are against not only their interests but of the whole productive chain of seeds, grains and animal farms. In a rather direct way, they demand an "audience with the President to explain why imports (of these items) should be banned." The letter was commented on the daily news briefing to the President, and it even has handwriting 
on it (unintelligible). At the same time, the Chamber managed to bring in a small group of grain producers that sent another letter to the President, complaining - in a naive way - that imports lower domestic prices, claiming this with obvious disregard for the potential benefits for consumers. Moreover, the importation of lard and (synthetic) detergents "is damaging for Mexico's peasantry" (es desventajosa para el campesinado en México). The letter, dated 12th of August 1950, stated that:

Because of the aforementioned reasons (imports lowering prices) we kindly ask you to boldly intervene in this matter as to prevent Compañía Importadora S.A. and Cámara Nacional de Comercio de la Ciudad de México from importing these items from the US, given its pernicious effects upon the economy (AGN, Fondo MAV: Vol., 895, Exp. 441(30)/1602).

It was clearly done in tandem with the Oil \& Soap chamber's efforts: first, the timing —one day after the open letter in Mexico City — and second, the odd claim that importation of synthetic detergents is damaging for "Mexico's peasantry." In other words, it is a clear attempt to bring the "peasants" into the fight. It is just the opposite from the powerful chamber: two poor peasants, Cesareo Jimenez and Magdaleno Cruz, from Comitancillo, Oaxaca, one of the poorest regions in the country. This discourse, presenting the producer as the raison d'etre of economic policy, permeated very much of the business community in Mexico, and not only those linked to the CANACINTRA.

The President's answer was two-folded: to refuse meeting the chamber's representatives, on grounds of "having all audiences cancelled as the President's devoting his time to the upcoming state-of-the-union address," as it was stated in the response (Telegram number 21058, 11th of August 1950. Sent to: Cámara Nacional de la Industria de Aceites, Grasas y Jabones, MAV, Vol. 895, Exp. 441/ 1602).

Furthermore, the Ministry of the economy produced a press release that addressed the issue in a more technical language:

Concerning the varied public statements made in the last few weeks by CNIAGJ members (Chamber of Oil and Soap producers) and other producers and businessmen requesting an absolute prohibition for importing lard and synthetic detergents, the Ministry of the Economy hereby declares that: As the CNIAGJ's board can attest, the government has been carrying careful studies of both internal and external market conditions for oleaginous seeds and grains, as well as about the needs of producers 
relying on oils and fats as key inputs. It has also maintained a policy of wide support to agricultural and industrial producers which has been translated into remarkable increases in domestic production, which is also a result of the positive engagement of the private sector with such policy.

Given output increases, the Ministry of the economy has established targets for import reductions of animal fats. Imports of beef lard have been banned and thus suspended completely, whereas importation of pork lard has been not only gradually reduced but kept under the exclusive right of CEIMSA (state-owned company). This in order to regulate the price and to avoid unfavorable competition from foreign products that would harm producers of these items.

The ministry of the economy has confidence that it will be possible, without damaging consumers, to ban in the near future imports altogether, given the low prices and improving quality of domestic production. For the definite triumph of Mexican producers' interests, the government will implement a set of measures that will only have, as boundaries, the satisfaction of the consumers at large [...].

Regarding the importation of synthetic detergents for household consumption, the Ministry decided to regulate it through the licensing system, as to avoid excess imports that could seriously damage the soap industry. However, an absolute ban of these items as requested by the Chamber of Oil and Soap industries was not implemented, considering that consumers' interests are superior [to those of the producers] (AGN, Fondo MAV: Vol., 895, Exp., 441).

The letter was published just a few days after the Chamber's first move, and not only in the Universal (one of the newspapers with the highest readership), but in all major newspapers. It was obviously intended to convince the public opinion that economic policy measures were taken according to technical criteria while at the same time insisting it would not damage industries or producers, as the chamber was claiming. Two elements of the letter's wording are worth emphasizing: First, it is clear that the government does not want to compromise its position to either group; rather, it starts acknowledging the private sector as a partner (the "positive engagement") and tries to convince the reader that it is possible to accommodate everyone's interest, that such clashes are not zero-sum games (minimizing the obvious fact that producers' interests are precisely at the expense of consumers). Second, the wording also reflects very accurately the narrative of 
ISI in Mexico: to start with, there is "unfavorable" competition; it is referred to in negative terms. So, the less competition, the better, is the bottom line. Consequently, imports are always a sign of weakness - attuned with Cepalismo, quite obviously. The "definite triumph" implies not only a race but cutting imports as the main goal. That is why what the government offers in the letter as the ultimate concession is the "absolute ban" of American lard and detergent. As a narrative for coping with particular demands it was perfectly suitable. However, internal documents prove the reality was otherwise.

It has been shown that beef lard was already banned. The SIC publicly declared so in the letter transcribed, and the measure was indeed officialized by being printed on the DOF the 14th of July 1950. Interestingly, in the Presidential archives there is also a special import permit that proves the government was, in fact, lying. First, beef lard was banned from being imported. Second, the state agency (CIMSA) was the only one authorized to trade any kind of lard and oil for the soap industry.

The permit quotes the tariff classification -1-23-39-(beef lard) is addressed to General Escobar and entitles "Comercial Inter-Americana, S.A." (a private firm) to import 5,000 tons through any custom in the following 180 days. It includes an explanation:

Mexico does not produce enough quantity of beef lard as to meet national demand [...] the quantity imported will be distributed across the country so as to not affect other similar products [...] Moreover, with the Korean War and the possibility of an international conflict, prices of all oils and fats are increasing fast so it would be convenient to buy as soon as possible. Of course, this permit and the acquisition of lard will be treated with absolute discretion and in a sensible way as to not disturb the market. (in Spanish: Desde luego el manejo de este permiso y la disposición del sebo se hará con toda prudencia y en forma reservada para no alborotar el mercado). There is an import committee for oils and fats formed by officials of the Ministry of Agriculture and representatives of the industry. Applications for import permits for these items are seldom given: the committee instructs the Ministry of the economy that such requests must be turn down. Therefore, this permit for 5,000 tons we are interested in must be processed OVER AND ABOVE THE OILS AND FATS COMMITTEE [capital letters in the original] (AGN, Fondo MAV: Vol., 895, Exp., 441[30]).

Clear enough, this is a straightforward case of successful rent-seeking. The words in italics and in capitals show that the grantee was very aware of 
the sensitive nature of the benefit given to him. "To not disturb the market" means not only preventing it from actually working properly allowing the price to fall, but also that disclosing the information would actually prove the government lied to the public in the letter.

The importer, with the permit, would gain from the facts that lard was in short supply — as a key input for the soap industry — and that restrictions to importing it had already increased its price. In that sense, the importer will benefit from the situation by which local producers of lard were already accruing rents. Therefore, the rents will come from either selling at the same price - or just marginally lower - or even at a higher price if the importer is able to hoard the lard long enough (betting that war would increase prices even more). In any case, the excess portion of the selling price would come not only from the fact that there is a captive market but also because even at the same selling price, the domestic producer faces higher costs.

Theoretically, this equals to the "Rising-Rivals'-costs" model of rents. The firm "Comercial Inter-Americana, S.A.," was competing with other local suppliers on selling lard and oil to the soap industry. Previously, Comercial Interamericana was buying lard locally. By getting the permit, it automatically cut costs and therefore widened profits, even if prices remain the same. Even if this firm was part of the soap industry - that was oligopolistic all throughout the twentieth century - the same model explains the logic: by being the only one with import permit, the competitors are forced to buy the more expensive local inputs

\section{RENT-EXTRACTION}

\section{Acapulco Customs}

Since the implementation of high tariffs and qualitative controls, the issues of smuggling, corruption and extraction of rents from custom officials was suspected, if not clearly known by the government, especially by the Ministry of the Treasury that had an interest in revenue maximization.

An example of this is the letter sent by the representatives of the Transport Chamber for the route Acapulco-Mexico City. It is dated October the 1st, 1956, addressed to President Adolfo Ruíz Cortines, and was stamped as received (and as confidential) by the President's Office. It gives an account of the exactions asked for in addition to the legal levies by a wide range of 
custom officials: from the warehouse keeper to the official in charge of approving the legal documentation (agente aduanal).

We expose to you the exactions truckers are subject to from Custom officials at the Acapulco Port, who, in addition to the levy they are entitled to charge, they charge drivers with the following payments to deliver the load to the highest bidder, a practice we consider unlawful. Such charges are as follows:

- Custom agents sell the load that arrives to the Port to the established (transport) lines at a rate of $\$ 20.00$ pesos per ton (sometimes up to $\$ 50)$ quantity that the driver has to pay from his money .

- In addition to this exaction, they send an employee to the gate, to whom drivers have to pay $\$ 5.00$ pesos per trailer (even though the official quota was already paid).

- Another charge is exacted by the federal employee attached to the Ministry of the Treasury who acts as Head of Warehouses. He has to be given $\$ 10$ pesos to issue the permit for loading in the Customs area.

As if these charges were not enough, the gate keeper asks $\$ 5$ pesos to let drivers in. All these exactions are imposed upon the finances of drivers, since custom officials charge the merchants separately for custom services and surcharges.

Moreover, even the workers loading the merchandise demand a payment for their work, even though this was already charged to the merchant in the "expenses bill." That is to say, these people charge twice for the same job."

The business is quite attractive to all of them, since, on average, the custom receives five thousand tons of merchandise every month, so at the minimum rate of $\$ 20$ pesos per ton, it means a profit of $\$ 100,000$ pesos a month to the custom official only. If we consider that such quantity takes at least 700 trips to be moved, it means a profit of $\$ 3,500$ pesos to the customs employee and the same quantity to the gate keeper, whereas the Head of the Warehouse pockets $\$ 7,000$ pesos a month.

We send this complaint on a confidentiality basis as to avoid retaliation and perjuries to our interests. We also do it in behalf of "Líneas Unidas del Sur", Transportes Independencia", "Transportes Figueroa" and "Central 
de Lineas" as the owners are afraid of speaking out because of the likely retaliation measures that would follow from the custom people, including the merchandise being seized altogether. That is why they are subject to this extortion ("exploitation" in the original) and it is, quite often, the firms' agents who personally deliver these payments to the custom officials. Custom officials also sell (illegally) merchandise to the firm "La casa de Oviedo," located in Acapulco.

This is against the Federal Law of Transport and Communications: transport of goods in bulk has to be done by authorized vehicles. However, the owner of this firm, who happens to be Spanish, simply pays a higher premium for the custom's people co-operation. Given all the aforementioned reasons we therefore urge to take the necessary steps to bring these people to court. We, other businessmen and the drivers are willing to provide evidence as to terminate this extortion." (This was signed by ten people: Serafin Ojeda, Ramón Laguna, José Romero, Jorge Rojas, Salvador Rizo, Raúl Figueroa, José García Cardenas, Héctor Camargo, Juan García and Arnulfo Rizo) Earlier reports had given account of this; the Ministry of the Treasury had been dealing with corrupt officials all throughout its existence, but it was clear that extortion was becoming widespread at customs as protective measures were on the rise (AGN, Fondo ARC: Vol., 464.564.2/597).

Not only the volume of trade had increased substantially, but also there were far many more regulations to follow — such as the Rule XVI that requires de identification of the product-that would mean more opportunities for rent-seeking. The President's correspondence of Adolfo Lopez Mateos contains an even more serious case of well documented rent-extraction and smuggling. The file, dated 7th of December 1960, addressed to Sr. Leon Garcia (complaints and suggestions Unit) acknowledges the letter sent by an administrative employee (Manuel Fernández) at the Tamaulipas-Laredo Custom:

(He) Denounces a number of staff and custom officials that allow smuggling at large scale, including luxury and sports cars. Specifies detaiIs of such activities and says will keep reporting. The $23^{\text {rd }}$ of October, while being on duty in the Old Bridge, gate number 1, in the shift from $22 \mathrm{pm}$ to 06 am (next day) the following personnel: private Rodríguez, three gate keepers and Official Vega, (I witnessed that) around 22:10 pm, right after the shift had started, there was a phone call from the sergeant instructing 
private Rodríguez to reinforce surveillance of the central office. He did so because he would interfere with Official Vega's intention of letting in a trailer with brand-new refrigerators. This operation had been planned and agreed in advance, given that they were able to present the "shipper export (certificate)." Don't you think his betraying the confidence you have on him, Mr. President?

[...]

Furthermore, on Nov. $4^{\text {th }}$, private Matamoros and three other gate keepers, while being in a station near La Joya, $135 \mathrm{~km}$ from the border, caught two cars driving south; a Chevrolet 1954 first, that was asked to show the relevant documentation. The driver showed a permit from March 1954, issued in Torreon. However, it is known that permits granted in such years match cars whose gauge is in kilometers, not in miles, as it was the case. I saw that while the private wrote the report to be sent to the station, the driver told private Matamoros to accept USD 200: he was not even the owner and was only delivering it (the private refused to take the money). Then, the second car approached. It was a Lincoln, model 1955 or 1956, with American plates but nothing more; the driver did not have any documentation to show. A report was also issued and sent to the station, and I wonder where those reports could be, as the cars were let free by the Officer in charge. If this information is corroborated, I personally will identify the drivers if required to do so. A third incident took place on the $24^{\text {th }}$ of November; this time, Commander César Munoz caught Capt. Macias on the spot: he let a cargo full of smuggled items in. Fortunately, the commander apprehended him and took him to the Central Office. Therefore, I will keep informing about such incidents (AGN, Fondo ALM: 564.2/608, number 29514).

Not surprisingly, cars - and especially the compact and luxurious ones - were amongst the items with a higher participation in the chronic deficit. Not only that, but also it proves extremely difficult in practice to control its importation, as the two last cases show.

For these reasons, we kindly ask you to reconsider the decision quoted in the previous letter and thus the permits can be granted to us. By insisting in getting the licenses, we do it because of the simple reason that we believe we are more entitled to it than the unauthorized retailers that do not face the same costs as we do and, moreover, because we are in this 
business since 1940. Looking forward to a favorable resolution, we kindly appreciate your consideration (AGN, Fondo ARC: 464.564.2/511).

This letter had not been the first one: the firm had already complained that the Ministry would deny authorization quoting that "given the fact that demand for this item in the domestic market is being met satisfactorily." Clearly, the Ministry was granting permits to import such cars (besides the smuggling that is) but subsidiaries of American firms were not the lucky ones.

This is a classic case of rents accrued by retailers, as modelled in Krueger (1974): it is about a final product whose importation requires a very scarce license. As such, the probability of getting it is low, but once a retailer gets it, profit margins are wide since there are no production costs. As statistics show, even though imports of small cars were kept relatively low, it was never completely stopped. In fact, it rose in both absolute and relative terms. Although it is difficult to quantify the size of rents with the data provided by these documents, they clearly show that trade policy during the fifties was more determined by the need to reconcile opposing interests than to reduce the deficit.

Moreover, most cases show the arbitrariness with which trade policy was conducted; in other words, the extent of cronyism. It also shows one of the limits of the ISI strategy in Mexico, that of technology: a recently created firm producing dozens of different models and under-investing in R\&D would never be able to compete with German expertise. In that sense, it shows the mistakes concerning technology transfer: instead of going through the technological ladder one step at the time, more often than not the Ministry would pretend (or being convinced) that firms were capable of substituting the entire product altogether.

By closing the domestic market entirely, firms would more often than not end with chronic over-capacity problems. In all, these items showcase of one of the major "sins" of ISI in Mexico: the priority given to the domestic producer not only at the expense of consumers, but at the expense of a better technology-transfer path and productivity gains. Moreover, as the decree by Ruíz Cortines show, top officials knew about these limitations, and at least in his case there was the willingness to correct the abuses. Sadly, time showed that rent-seekers were far more successful than economic planners. 


\section{A SNAPSHOT OF QUANTITATIVE EVIDENCE}

In itself, the analysis of this data brings new evidence to light and as such contributes to the wider literature of trade policy in Mexico. In terms of results, the evidence supports the claim that quantitative controls were in fact being used as protectionist devices right from the onset, not until the late 60 s as previously thought.

Specifically, this entailed the construction of a dataset based on the DOF where all new laws, decrees and amendments were published, and thus effectively enacted. As such, the SIC was obliged by law to publish in the DOF every single inclusion (as well as exclusions) into the list. Most decrees would include one item at the time; although some decrees would include dozens at once (see below). In short, a quantitative analysis of import-licensing was carried out, using decrees for inclusions/exclusions of items being protected from trade, in order to answer two questions: Did the import-licensing system have consistency? Is it possible to identify redundant protection through it?

Table 1 below captures core numbers regarding decrees granting protection, its average length and accumulated protection, for the 1966-1980 period. That is, computing the stated length of protection through licensing (its expected duration) and adding up the time for each year's total of items banned, we obtain the following results: the single year with the highest accumulated time was 1974, closely followed by 1973 and 1971, whereas the years with the highest number of expiring inclusions were 1972 and 1973. Taking the average length of inclusions, the first two years are clearly the highest: 4.96 and 5.17 years per item banned in 1966 and 1967, respectively, versus 1 for the rest of the years.

This marked difference is explained by the fact that only for those years 10-year bans were included, along with many 5-year ones. In that sense, it is clear that even for the record, the government was willing to grant protection for the long run. Even if ten-year bans were not imposed after 1967 — thus lowering the averages - it is clear from table 1 that net length of protection was being extended considerably since the late sixties and especially after 1970 . This is hardly a surprising finding since it coincides with Echeverria's administration (1970 to 76), well-known for its efforts to "deepen" industrialization, fostering new industries and pressing for a state-driven, fiscally unsustainable activism which would ultimately result in the 1976 crisis. 


\begin{tabular}{|c|c|c|c|}
\hline Year & $\begin{array}{c}\text { Aggregate accumulated } \\
\text { protection (years) }\end{array}$ & $\begin{array}{c}\text { Number of decrees } \\
\text { granting protection }\end{array}$ & $\begin{array}{c}\text { Average length of } \\
\text { protection granted }\end{array}$ \\
\hline 1966 & 129 & 26 & 4.96 \\
\hline 1967 & 626 & 121 & 5.17 \\
\hline 1968 & 132.5 & 67 & 1.98 \\
\hline 1969 & 179.6 & 116 & 1.55 \\
\hline 1970 & 365.7 & 256 & 1.43 \\
\hline 1971 & 494.7 & 311 & 1.49 \\
\hline 1972 & 414 & 531.5 & 1.59 \\
\hline 1973 & 577.9 & 458 & 0.78 \\
\hline 1974 & 751.5 & 553 & 1.26 \\
\hline 1975 & 167.3 & 128 & 1.36 \\
\hline 1976 & 49 & 67 & 0.73 \\
\hline 1977 & 9 & 8 & 1.13 \\
\hline 1978 & 16.5 & 18 & 0.92 \\
\hline 1979 & 59 & 58.5 & 1.01 \\
\hline 1980 & 29 & 32.5 & 0.89 \\
\hline
\end{tabular}

Table 1.

Length of trade-protection temporariness per year (years)

Source: author own's calculations from 3,754 decrees compiled DOF decrees.

An even clearer picture emerges by doing a simple exercise of extrapolating the due date of the licensing, as stated in the decrees, with the actual reversals, so as to measure the extent of un-reversed import bans.

Left column on table 2 presents the accumulated number of items being classified as licensed for one year only; that is, only items due the following year, which account for roughly $60 \%$ of all. It is clear that the actual (observed) reversals are far lower than they should have been. In other words, by 1980, the tally of reversals for one-year bans should amount to 1,377 , whereas the totality of observed reversals reaches 387 . That is, 990 short of its expected, strictly speaking, it is not completely accurate to subtract the observed reversals from the expected reversals column, since the former includes items that were banned prior to1996. It is, again, about thinking on a best-case scenario. Besides this point, it should be noted that, had the rest bans ( 2,4 and 5 years and so on) been included, the gap would be even wider.

What these two tables show is that, even in its own terms, the system did not have consistency; failure to meet its own-set goals of temporariness is in itself evidence that domestic producers were managing to extend the protection granted to their products. It is also evidence that using inclusions 
Table 2. Extrapolation: expected (trade-protection) reversals vs. observed reversals (yearto-year basis only)

Source: author own's calculations from DOF compilations. is a rather good proxy for protection: had it not been the case that an inclusion equaled no licenses issued (i.e., successfully getting rid of competing imports) neither the government nor the private sector would have been adamant to implement such reversals. In sum, the clear trend of endless extensions clearly points toward rents being accrued.

\begin{tabular}{|c|c|c|}
\hline Year & $\begin{array}{c}\text { Expected reversals of protection decrees } \\
\text { (given stated length in previous decrees) }\end{array}$ & $\begin{array}{c}\text { Actual, observed } \\
\text { reversals }\end{array}$ \\
\hline 1968 & 16 & 10 \\
\hline 1969 & 58 & 42 \\
\hline 1970 & 138 & 73 \\
\hline 1971 & 296 & 76 \\
\hline 1972 & 432 & 114 \\
\hline 1973 & 716 & 71 \\
\hline 1974 & 1002 & 0 \\
\hline 1975 & 1291 & 0 \\
\hline 1976 & 1349 & 0 \\
\hline 1977 & 1350 & 0 \\
\hline 1978 & 1357 & 0 \\
\hline 1979 & 1365 & 0 \\
\hline 1980 & 1377 & 14 \\
\hline
\end{tabular}

Furthermore, the data also allows for a classification according to item and item type, which also brings new data to light. The total of disclosed (i.e., product's name or description available) banned items between 1947 and 1980 amounts to 4,625. However, there are 372 undisclosed decrees of which at least half contain more than one product (it reads "others").

In sum, while there was a grand total of 3,754 inclusions (items, not decrees) and 409 deferrals, there were only 393 reversals during the whole period. Even after 1967, when the inclusions would start having a clear time limit, the observed reversals were literally negligible: they would reach their peak in 1972, at 114, only to flatten at 0 in 1974, whereas the expected reversals by year was over 1,000 by 1974 . 


\section{CONCLUSIONS}

Sample cases showcase the limits, tensions and misuse pertaining to the import-licensing system, which facilitated and accelerated rent-seeking activities. Take the tin-industry case: the market saw the price of a tin pound to increase from USD 1.03 to 3.16, right after licensing was introduced. Not surprisingly, President Ruíz Cortines was forced to reckon, in a 1954 decree, that:

In practice, it has been the case that some firms have used protection only to obtain disproportionate profits at the expense of consumers and against the interests of the society at large (AGN, Fondo ARC: 464.564.2/597).

Regarding Rising-Rivals' Costs rents, the case of the soap industry is the most telling; as part of the import-substitution process, local suppliers of lard managed to get protection, thus imposing higher costs for all soap-making firms. However, the one owned by a former army officer gets a permit to import 5,000 tons of lard at once. The internal documents clearly show the extent to which the SIC was aware of the sensitive nature of the permit, thereby keeping it secret. It was, by all means, cronyism.

On Rent-Extraction by extortion, the case of Acapulco customs shows how extensive it was: businessmen were so fed up that they took up to meticulous letters describing every detail of it.

Finally, the quantitative evidence does support two core conclusions: (i) quantitative controls were in fact being used as protectionist devices right from the beginning, not until the late sixties as previously thought; and (ii) import-licensing failed to meet its own-set targets for reversing protection, thus lacking internal consistency and facilitating rents to be accrued. The government did in fact grant gracious privilege to an important number of firms and industries and kept doing it for far longer than it should have had to.

Granular evidence has been provided on a key element of non-tariff trade controls: it diverts public, private and social resources, hitherto devoted to growth, into securing and expanding rents up to a point at which is far costlier for the whole economy to keep controls than simply allow imports again. That is, economic autarky is not only unworkable and ineffective, it makes everyone worse-off. 


\section{REFERENCES}

\section{Primary sources}

\section{Archival materials}

Archivo General de la Nación (AGN), Mexico City, Mexico.

Fondo 217:

Sección 554, Volumen 511.01/727, Expedientes. 7, 8, 13.

Sección 554, Volumen 564.2/347.

Sección 557, Volumen 13.

Fondos presidenciales:

ARC (ADOLFO RUIZ CORTINES):

$564.2 / 347$

$564.2 / 358$

$564.2 / 511$

$564.2 / 597$

MAV (Miguel Alemán Valdés)

$895-441 / 1602$

$895-441(30) / 1602$

Fondo de Hacienda:

1953 - Volumen 3, Expediente 12.

Fondo Diario Oficial De La Federación, 1947 to 1980.

\section{BIBLIOGRAPHY}

Buchanan, J. M., Tollison, R. D., \& Tullock, G. (eds.) (1980). Toward a theory of the rent-seeking society. A and $M$ University Press.

Congleton, R., Hillman, A., \& Konrad, K. (2008). 40 years of research on Rent Seeking (Vols. I \& II). Springer-Verlag. https://doi.org/10.1007/978-3540-79182-9

Haber, S. (ed.). (2002). Crony Capitalism and Economic Growth in Latin America. Hoover institution Press.

Khan, M., \& Jomo, K. S. (2000). Rents, Rent-seeking and economic development. Cambridge University Press. https://doi.org/10.1017/ CBO9781139085052 
Krueger, A. O. (1974). The political economy of the rent seeking society. American Economic Review, 3, 291-303.

Krueger, A. O. (1975). The benefits and costs of import substitution in India: a SICroeconomic Study. University of Minnesota Press.

Krueger, A. O. (1990). Government Failures in Development. Journal of Economic Perspectives, 4(3), 9-23. https://doi.org/10.1257/jep.4.3.9

Krueger, A. O. (2002). Why crony capitalism is bad for growth. In: Haber S. (ed.), Crony Capitalism and Economic Growth in Latin America. Hoover Institution Press

McChesney, D. (1997). Money for nothing: Politicians, Rent Extraction, and Political Extortion. Harvard University Press.

Peltzman. S. (1976). Toward a more general theory of regulation. Journal of Law and Economics, 19, 211-240. https://doi.org/10.1086/466865

Peltzman, S. (1989). The Economic Theory of Regulation after a Decade of Deregulation. Brookings Papers: SICroeconomics, (special Issue), 1-41. https://doi.org/10.2307/2534719

Posner, R. A. (1974). Theories of Economic Regulation. Bell Journal of Economics and Management Science, 5(2), 335-358. https://doi. org/10.2307/3003113

Rubio, L. (1990). El sector privado en el pasado y en el futuro de México. In J. Wilkie \& A. Reyes (eds.), Industria y Trabajo en México (pp. 243-262). Universidad Autónoma Metropolitana.

Stigler, G., J. (1971). The Theory of Economic Regulation. Bell Journal of Economics, 2(1), 3-21. https://doi.org/10.2307/3003160

Tullock, G. (1967). The Welfare Costs of Tariffs, Monopolies and Theft. Western Economic Journal, 5, 224-232. https://doi. org/10.1111/j.1465-7295.1967.tb01923.x 